\title{
Iatrogenesis in Intensive Care Units: Dramatization of Contemporary Bio/Ethical Problems
}

\author{
Mara Ambrosina de Oliveira Vargas ${ }^{1}$ \\ Flavia Regina Souza Ramos
}

This qualitative investigation, based in Foucauldian analysis with approximations to the post-structuralism theoretical framework, explores iatrogenesis as one of the tensions in the nursing to do/to know which can be discursively articulated to bioethics and to technobiomedicine. The documentary sources and intensive interviews with nurses, permitted the activation of a reflection on the act of the nurse in a context permeated by the ever-present possibility of failure in both the procedure and in the conduct and, from this possibility, they should meet their obligation to correct this failure not so much or not only in knowledge, not so much or not only in law but in practice itself.

Descriptors: Intensive Care Units; Nursing; Bioethics; Ethics; Iatrogenic Disease.

${ }^{1}$ RN, Ph.D. in Nursing, Adjunct Professor, Universidade do Vale do Rio dos Sinos, RS, Brazil. E-mail: maraav@unisinos.br

2 RN, Ph.D. in Nursing Philosophy, Associate Professor, Universidade Federal de Santa Catarina, SC, Brazil. E-mail: flaviar@ccs.ufsc.br.

Corresponding Author:

Mara Ambrosina de Oliveira Vargas

Universidade do Vale do Rio dos Sinos. Departamento de Enfermagem.

Av. Unisinos, 950

Bairro Cristo Rei

CEP: 93022-000 São Leopoldo, RS, Brasil

E-mail: maraav@unisinos.br 


\title{
Iatrogenias nas unidades de terapia intensiva: dramaticidade dos problemas bio/éticos contemporâneos
}

Esta é uma investigação qualitativa, balizada na analítica foucaultiana com aproximações ao referencial teórico pós-estruturalista, explora as iatrogenias como uma das tensões no fazer/saber enfermagem que podem ser discursivamente articuladas à bioética e à tecnobiomedicina. As fontes documentais e de entrevistas com enfermeiros(as) intensivistas permitiram ativar reflexão sobre o agir do(a) enfermeiro(a) em contexto permeado pela possibilidade, sempre latente, de falhar tanto no procedimento como na conduta, e, a partir dessa possibilidade, ele(a) encontra sua obrigação de corrigir essa falha não tanto ou não apenas no conhecimento, não tanto ou não apenas na lei, mas na prática de si mesmo.

Descritores: Unidades de Terapia Intensiva; Enfermagem; Bioética; Ética; Doença Iatrogênica.

\section{Las iatrogenias en las unidades de terapia intensiva: lo dramático de los problemas bioéticos contemporáneos}

\begin{abstract}
Se trata de una investigación cualitativa, fundamentada en la perspectiva foucaultiana con aproximaciones en el referencial teórico post-estructuralista, explora las iatrogenias como una de las tensiones en el hacer/saber enfermería que pueden ser discursivamente articuladas a la bioética y a la tecnobiomedicina. Las fuentes documentales y de entrevistas con enfermeros intensivistas permitieron activar una reflexión sobre el actuar del enfermero en un contexto impregnado por la posibilidad siempre latente de fallar tanto en el procedimiento, como en la conducta y, a partir de esta posibilidad, estos profesionales encuentra que es su obligación corregir esta falla no tanto o no apenas en el conocimiento, no tanto o no apenas en la ley, pero más bien en la práctica de sí mismo.
\end{abstract}

Descriptores: Unidades de Terapia Intensiva; Enfermería; Bioética; Ética; Enfermedad Iatrogénica.

\section{Introduction}

The emergence, the immediacy and the drama of the situations experienced in the Intensive Care Unit (ICU) lead to ethical problems, in these places, being often more evident, tempestuous and heavy ${ }^{(1)}$. In the context of ICU, the employment of high technology has been perceived as a factor responsible for adverse events. And, even recognizing its many benefits to patients, it can trigger serious damage when it is not the object of careful vigilance(2).

The discussion of iatrogenesis can be expressed in terms of technical failure and failure of conduct and in the conceptualization of the ethical and legal violations of these failures. Technical failures are those related to technical or procedural errors; and the failures of conduct those related to attitude, to behavior and to the inter-personal or inter-professional approach. The ethical occurrence consists of some kind of mistake committed by the nursing professional, which results in harm to the client. In turn, from the ethical-legal standpoint, negligence consists of inaction, inertia, passivity or omission, being negligent the person who, could or should act in a determined way and through indolence or mental laziness, does not act or behaves differently. Malpractice concerns the lack of knowledge or technical training or the ability to perform certain tasks. It is therefore a commissive attitude (to commit or act) by the professional, exposing the client to risk. Finally, imprudence results from precipitated action 
without due caution. The professional who exposes the client to unnecessary risk or makes no effort to minimize them is imprudent ${ }^{(3)}$.

The word iatrogenesis derives from Greek and is composed by iatrou, which means "healer" and genesis, "origin". However, although having a specific morphological meaning, the term has been used widely to identify a harmful action. Iatrogenic disease is a disease caused by the doctor, by one of his assistants, by the pharmacist or by the nurse ${ }^{(4)}$.

Iatrogenesis, ethical occurrences, adverse events, negative critical incident and failure are terms used to cover the same type of discussion. Terms regularly, defined as "undesirable events, that cause harm to the physical or moral integrity, related to interventions provided by the nurse, nursing technician or nursing assistant, able to compromise or with the potential to compromise patient safety"(2). A security that, in 1988, was already flagged as maximum priority in the $\mathrm{ICU}^{(4)}$ and, at present, continues to be expressed in studies that reinforce the discussion of the characterization of adverse events in the ICU, is the identification of the interventions of the nurses after the occurrence of the event $^{(5)}$. Another study highlights the issue of patient safety, addressing the potential drug interactions in the ICU and their respective clinical management by the nurse to minimize or even avoid these interactions ${ }^{(6)}$. In turn, our contribution to the discussion of iatrogenesis, focuses precisely on the philosophical analysis approach adopted, which allowed us to discuss the ways the nurses constitute themselves as ethical subjects.

Thus, buoyed by the expression "disease aroused by the nurses", a Foucauldian analysis was used with approximations to the post-structuralism theory, with the aim to explore some of the tensions in the to do/to know of nursing that can be discursively articulated to bioethics.

\section{Methodology}

This article is part of a thesis which analyzed the relationship of technobiomedicine and bioethics, as contemporary discourses, implicated in the production of the subjectivity of the nurse in the context of the ICU. The study was conducted in two stages: a literature review and an empirical stage. In reviewing the literature, the documentary corpus was composed of articles published by Brazilian nursing, in the period 1984 to 2007. Articles published in national nursing journals, which reached, in any year between 2000 and 2007, International A or B grade by the Qualis system (Latin American Journal of Nursing; Journal Acta Paulista de Enfermagem; Text \& Context Nursing; Journal of São Paulo University School of Nursing) were included as articles to be investigated. Additionally, we included the REBEn, because it configures into a flagship journal for Brazilian nursing, and the O Mundo da Saúde Journal, aware that many nurses publish in journals specific to bioethics. In the respective periodicals, 113 articles were located through a broad manual search, delimited by themes that could enrich the discussion on the issues of bioethics and the ICU. Therefore, besides guiding the search with the descriptors bioethics and ICU and nursing, ethics and ICU, bioethics and nursing, this was expanded, because although articles do not explicitly reference the term bioethics, the matters discussed reproduced themes directly related to bioethics and ethics. Among these 113 articles, six that focused on the issue iatrogenesis and three that approached the Ethics Committees in Nursing (ECN) were selected.

In the empirical step, an exploratory study with a qualitative approach was carried out. The population consisted of 20 (twenty) nurses working in different ICUs, in the Metropolitan Region of Porto Alegre. For this, semi-structured interviews were conducted and recorded with one or two nurses by institution, with minimum experience of six months. First, they were contacted by telephone and asked about the possibility of responding to an interview. In the case of preliminary acceptance, a day, time and place was scheduled due to the availability of subjects. The project was approved by the Ethics Committee ( $n^{\circ}$. 186/07/CEP/UFSC) and the subjects expressed their acceptance by signing the Free Prior Informed Consent form, according to Resolution 196/96.

The theoretical and analytical approaches used in this study were guided by Foucault and gather the results of the two stages (literature review and empirical research). In this sense, articles and interviews were approached through the narrative of a particular historical period. On one hand, the stories that were narrated to us through the interviews have become documents produced in the culture through language, in the meeting between researcher and research subjects; documents that have acquired different meanings when analyzed in the context of the theoretical framework, of the time and of the social and cultural circumstances. Conversely, the articles, considered as narratives, obeyed the above, but, perhaps, they showed in a more stark way a number of authorized subjects, supported 
by institutional status or as specialists that use the academic discourse, when talking about themselves and others, when describing and characterizing the others. Finally, we work with the interviews and articles as a connection between discourses that are articulated, which overlap, which add to, or even which differ or contemporize themselves.

\section{Presentation of Results and Foucauldian Analysis}

Perhaps due to the conflictual character of the theme iatrogenesis, most of the nurses interviewed said almost nothing about iatrogenesis in their daily practice in the ICU. Thus, between the almost nothing stated and the non-said of the theme iatrogenesis, we expose, the following found in the articles and in the excerpts from interviews with the nurses.

\section{Diseases triggered by nurses: the said in the articles!}

In the articles analyzed, the authors detailed the description of the type of faults detected and reported in the context of the ICU and in the consequent physical and psychological damage to the subjects involved. In the $\operatorname{article}^{(7)}$ that discusses Cardiopulmonary Resuscitation (CPR), the need is emphasized for professionals to follow the rule understood as the current best, and the indication of the presence of a coordinator of activities is enhanced. Still, all the articles point out the need to intervene immediately, to implement strategies or preventive measures, and to prioritize the prevention of errors rather than punishment.

The first $\operatorname{article}^{(8)}$, among the three that address the issue of Ethics Committees in Nursing (ECN) in their relation to iatrogenesis, verified indications of ethical violations present in the accusations charged against the nursing professionals, which were verified by the institution through investigations and administrative disciplinary proceedings. From this verification, the article expressed that in the units, among these the ICU, where there is a demand for more attention in patient care, greater control of nursing actions occurs by all work team members, which could help to optimize the identification of ethical faults. The second article ${ }^{(9)}$ was concerned with comprehending the significance of the actions of nurse managers and nurse members of the ECN faced with the ethical occurrences involving nursing professionals. The experiences of these nurses helped to uncover what they seek, among other aspects: continuous improvement of the care process, professional credibility, satisfaction of the clientele, the demystification of the fear of punishment, the partnership in the educational process. The third article(10) argued that all efforts of the nurses would be insufficient for coping with ethical events in nursing if there was not a process of partnership between the institution and professionals in the health area, to commit themselves ethically, with an institutional goal of ensuring the security, integrity and respect for the rights of the patient, co-worker and their own rights, as professionals and citizens.

\section{The question of the dilemmas, the drama of every event}

"The truth for Foucault is not exposed, however, in the calm element of discourse, as a distant and fair echo of the real. It is, in the most fair and literal sense of the expression, a reason to live, or a logos updated by existence, and that animates, intensifies and proves it: verifying $i t^{\prime \prime(11)}$. Foucault, when referring to the Greeks of the I and II centuries of our era, shows us an understanding of the relationship subject and truth distinct from that conveyed by the Modern Age. In this different understanding, the subject is not capable of truth, but the truth is able to transfigure the subject. In turn, in Modernity, the truth is not able to transfigure the subject, but the subject is capable of truth. That is, in Modernity, with Descartes as a reference compounded by Kant, although under the effect of a whole series of complex transformations, the moment arrives in which the subject, as such, became capable of producing the truth. The model of scientific practice had a considerable role: it would be sufficient to reason in the correct way and, to constantly maintain the line of evidence without ever deviating, to be capable of truth. Therefore, it is not the subject who should be transformed. It would be enough that the subject were who he was to have, by the knowledge, access to the truth, which was opened by its own structure of subject(11).

However, the issue of ethical dilemmas, i.e. the drama of the events in intensive care, is shown to be emblematic for thinking in a somewhat paradoxical relationship of subject and truth. Sometimes we have the modern subject producing the truth; other times we are facing a subject who needs believable and plausible reasoning, capable of transfiguring the subject, modifying it. The extreme of the opposition and the extreme of the indivisible are in force. A strong opposition between the need for action, as methodical scientific knowledge capable of truth, and the need for 
attitude, as a conjecture, a way to navigate on the edge of the conflict; an inseparable link between the need for knowledge and a way of caring.

At the extreme of the indivisible, Foucault refers to the arts of conjecture and exemplified them through the command of a ship and the medical care. In these, from beyond the exact truth, none, except the sensitivity of the body, would be found; we would have an arduous job to understand a science sufficiently precise to not commit any, other than mild, mistakes; still, the absolute security of a judgment would be a rare spectacle: every activity is both rational and uncertain. While the bad sailor rules in calm weather, when committing an error, the error does not appear; but when surprised by a big storm and a violent headwind, everyone can then see with their own eyes that it was his inexperience and inability that lost the ship ${ }^{(11)}$.

Some of the elements of discussion are made visible in the statements below:

Sometimes, a failure results in a chain of things that happen improperly. A newly formed nurse, recently employed in the ICU, authorized the nurse technician to close the infusion pump of norepinephrine during the transfer to the surgical ward; she did this through not understanding the dangerous effect of this attitude. The surgery of the patient was suspended by the worsening of hemodynamic instability. The patient was hurriedly moved to the ICU; the worsening of hemodynamic instability was reversed in the ICU and the patient underwent surgery on the next day. The medical and nursing team made the nurse responsible for what happened. The nurse blamed herself for what happened. Some time later, the nurse was punished with a written warning and transferring her from the sector was considered. The time passed, the counter-arguments of the nurse who made the mistake increased and she expressed that she liked her job and had learned from the whole situation. She ended up staying in the sector. (S5)

What triggered the removal process of the nurse from the ICU was not only the fact that she had committed a grave error when she administered the drug; what mobilized the whole team against her was the disregard with which a professional, who had worked a considerable time in the ICU, handled the incident with the relatives of the patient, and tried to blame other professionals for her error. Not admitting the error is the worst thing that can happen in the ICU. (S20)

Although the statements were from interviewees that work in the ICUs of different hospitals, they came together in a unique way. Apart from the technical failure of both nurses, which reverberated for the good and for the bad, in these statements were precisely their attitudes, the way they proceeded. One transfigured bad into good ${ }^{(11)}$; believing that what was required from her was to assume the bad that was done, to get afflicted with this and this affliction was also bad; afterwards, she valiantly supported this, transformed it into experience, thus promoting the nullification of this bad; this depended on her and was a good.

The excerpts also signal the length of experience of nurses. In one article analyzed ${ }^{(12)}$ the notion is contemplated that when the time working in the ICU is shorter, nurses are more sensitive to the problems experienced, being that the more experienced would have more consolidated defenses. Again, what crosses these arguments is the way of conducting themselves. From the analytical framework adopted in this study, it would be considered that the behavior, the adopted attitude, not only compromises the other. In the uniqueness of all conduct, in the immediacy of each event, the misfortune of knowing the best way and not doing it, of ignoring and so not doing good; of doing bad and denying knowledge of this bad; and of not preventing the bad, operate in the subject; and with this, inexperience and inability are demonstrated.

Misfortune is a good in the same measure that it is a misfortune, in which it is recognized as misfortune by the attitude of trial(11). The idea of "life as trial former" is useful to think the way an unfortunate act, an error, a trial, is also the occasion to evoke some principles, reactivate rules and remember what was done. For this evocation, the subject can see their ability to react in accordance with these principles; due to the reactivation of the rules and from remembering of what was done, the inadequacy between the rules that were remembered and the actions committed can be evaluated; thus it can measure at which point the person is as an ethical subject of truth. That is, to ask themselves: to which point am I someone effectively able to be the identical subject of action and subject of truth? Or: to what extent the truths that I know, and what I verify that I know, because I remember them as rules, through the examination of conscience that I do, are effectively the forms and the rules of action, the principles of action of my conduct throughout the day, throughout my life? At which point am I in this operation that allows me to perfectly match in me the subject of knowledge of truth and the subject of the straight action(11)?

We believe that we should remain with this argument of Foucault ${ }^{(11)}$, because it includes the notion of culture of self. A culture of self, reached over a scale of the entire life, consists of educating oneself through all the misfortunes of life. One should continually educate 
oneself through the trials that are sent and though the care of oneself, which causes these trials to be taken seriously. To educate oneself throughout the whole life and at the same time, to live in order to educate oneself. Coextensivity between life and formation is a possible feature to think about life organized as trial(11).

To finalize, it is precisely from this coextensivity between life and formation that we return to the arguments about the length of experience as a nurse versus knowledge, in the way that iatrogenesis and the possibility of making mistakes are dealt with. Life as trial is the whole life and not from the moment in which one becomes an intensive care nurse. What do we perceive as a subjectivization process exactly at the moment of being a nurse in the context of intensive care? What changes there, is the drama of the event, its sharpness, its immediacy, which leads the professional to develop their action from a rule, from a principle, that they both learned in ICU and acquired in the coextension of their life, but readily applied in the ICU, to the extent that it was needed.

From this perspective of analysis, ethics are not dependent on a concept of human nature, but on the practice people do, "it is centered on a matter of personal choice, on the aesthetics of existence". The stylized construction of the ethical subject does not happen through categorical moral rules, but according to an art of living that starts with the choice of practices and ideal formulas known socially. The most important decision is the one that individuals take in relation to themselves and to the others, the anesthetization of ethics, as a process of creation and construction of novel techniques, in which the subject manages their own freedom. Therefore, Foucault distinguishes the moral, "as a set of values and rules of proposed actions to individuals and groups through various prescriptive devices", through ethics, namely the "elaboration of ethical work that happens by itself, not only to make its own behavior according to a given rule, but also to try to transform itself into a moral subject of his own conduct"(11).

When it is said the disease aroused by nurses, at the same time it is revealed that technology should be able to foster alert conduct in order to identify the ethical dilemmas produced both in its development, and in its application ${ }^{(13)}$. As an example, one could cite here the process of mechanical ventilation, of hemodynamic monitoring, among other ways of caring in ICU connected to biomedical technology. But, to reinforce this aspect with the example of the characteristics of drugs frequently used in the treatment of critically ill patients, i.e. vasoactive drugs, anticoagulants, potent antibiotics, sedatives, among many others, that are identified as predisposers of iatrogenic occurrences because of the potential risk they present. To execute the administration of medication there is the requirement from professionals, especially nurses, of broad technical and scientific knowledge related to the preparation, administration and control of effects of drugs as the basis for the determination of the nursing care. This requirement is covered by special care when it comes to drugs used in the ICU ${ }^{(12)}$. Thus, there is a need for much discussion among professionals involved in the process of administering medication ${ }^{(14)}$.

Even centralizing the example in drugs used in ICU, the articles analyzed so far and expressed in the article above, indicate that the exact extent of the error, in various situations experienced, is complex. In this articulation with technology, we are mostly in a position of near or total ignorance. That is, we have reached an extreme level of ignorance in the face of technology. We do not necessarily know how the technological apparatus we handle works. The awareness of the technique, exactly in its exacerbation, reveals its fragility. Unlike the Neolithic human, the cybernetic human can no longer distinguish the technique from nature, or the meanings of the technique from its relationship with nature. Both the ambiguity of the technique and the fragility of the awareness of the technique are marks in its conflictive character. And nothing can evade this conflict(15).

The articles analyzed, in several ways, point out the need: to intervene immediately, to implement preventive measures and to prioritize the prevention of errors rather than punishment, as this may lead to under-reporting of iatrogenesis. In turn, regarding the difficulty of preventing the disease aroused by nurses, a nurse noted:

The lack of commitment of many professionals with the institution, errors or technical failures such as, for example, inadequate evaluations and interventions that are not recommended and that pass with impunity. The impunity bothers me a lot and generates neglect, lack of responsibility, lack of human resources, of materials and equipment for qualified care. (S1)

The tension now is between preventing and punishing, but not between prevention and impunity. Impunity is defined by the dictionary as "the lack of deserved correction" and punishment as "a correction". For better prevention, professionals need to notify, monitor procedures, and correct situations of risk. But the way in which the noun punishment is being used in our 
context, acquires an attitude of castigation performed, and not necessarily the effectiveness of the correction. A correction that, in this case, would require the opening to speak and the freedom of play. A game that makes possible, in the field of the knowledge taken as true, the use of the knowledge pertinent to the transformation, to the modification and to the improvement of the subject. A type of discourse that, at the same time says what is true and what should be done, a discourse that unveils the "best" truth and prescribes it(11). A parrhesia, translated in general as "frankness, openness of thought, openness of heart", is a rule of the game, a technique used, a principle of verbal behavior that we have to take in relation to each other in practice, in the direction of consciousness ${ }^{(11)}$.

The parrhesia (the frank-speaking) is this essential form to the word of who leads: the free word, rid of rules, in the meaning that on one hand, it should certainly adapt to the situation, to the occasion, to the particularity of the listener; but above all, it is a word that, from the perspective of one who pronounces it, has the value of a commitment, has a value of a link, constitutes a certain pact between the subject of enunciation and the subject of conduct. The subject who speaks compromises him/ herself. At the moment that the subject says "I tell the truth", they undertake to do what they say and to be a subject of a conduct, a conduct which they obey, point by point, to the truth formulated by them ${ }^{(11)}$.

Aiming to further scrutinize the ways of being a nurse in the ICU, in the articulation of the bio/ethical discourse with technobiomedicine, we consider it productive to bring together the analysis of preventive strategies addressed in the articles, with the thought about the future. A thought about the future that would seek to prevent the bad (praemeditatio maloru), an exercise that would be to make the human equip themselves with true discourses. In praemeditatio malorum, all possibilities are considered, or at least the worst. It is not about a future with some uncertainty. It is about considering that everything that can occur must necessarily occur. It is a type of immediate time, concentrated in one point, considering that the worst misfortune that somehow will occur, is already present(11).

It is an annulment of the future within the interior of this distrust, an annulment of the future faced with the presentification of all that is possible in a type of current trial of thinking. Simulation of the future is not started from the present: all the future is considered to simulate it as the present ${ }^{(11)}$. Therefore, in the preventive strategies, the intensive care nurse should consider all possibilities - and they are many - of events that could happen to the seriously ill subjects. So we spend the day considering that everything that can occur must necessarily occur, thus in this predictable consideration, we try to annul what has to occur. But how can this be done? How can the annulment of the future be carried out in practice? This is what the articles that deal with iatrogenesis approach; they both break down the possible occurrences and indicate the preventive strategies. It is in this that the nurse clashes, due to their observation of the absence of preventive strategies:

Unpreparedness of the team during CPR, lack of agility and skill has resulted in many problems in performing the task. I failed in the management of this process, I believed that the team knew their roles and I did not review it. (S10)

Therefore, it is believed that the iatrogenic occurrences identified, for example, during the care of CPR in the ICU, can be triggered either by the absence of a coordinator of activities, or by the absence of a care protocol placed strategically within the ICU(7). And yet, with the occurrence of any failure, intensive care nurses are expected to make decisions that lead to prevention of undesirable complications ${ }^{(12)}$.

Therefore, it is imperative that the managers of nursing services know how to make the upper management of the institutions committed in the sense that the quality and safety of nursing care are rights of society. This requires, from the institution, administrative, ethical and legal responsibility for the human resource dimension, investing in human and material resources in order to minimize their legal responsibility in the face of iatrogenic occurrences to the client. It is necessary to prevent ethical occurrences through the combined efforts of nurses and the effective involvement of other nursing professionals, in the several instances, that can be in continuous education, or in the ethics commissions. Here the following proverb is valid: prevention is better than cure(3).

Finally, the nurse that manages, considering the drama of the event, acts precisely in the promotion of a style, as well as the formation-knowledge. Hence, the need for coordination by the other is based mainly on the fact that the subject is less ignorant than malformed(11). Therefore, it is not only toward a knowledge that replaces his ignorance that the subject tends. The individual tends toward a status of subject. S/he must constitute him/herself as a subject and it is on this that the other intervenes(11). In the case, of being better to prevent than to remediate, the nurse is the one that seeks, in addition to aggregate and transmit knowledge, 
to operate in the formation of the individual as subject. It is, therefore, a reform of the attitude, of the actions of the subject that are also included in the complex process of preventing iatrogenesis and adverse events.

\section{Final Considerations}

To analyze a bio/ethical theme in the context of the ICU may produce a discussion combined with the quotidian relations of the nurses working there. The intention was to discuss an issue that happens in the ICU, which is committed to a process of caring that is not neutral or unaware of the ways of being and doing of the subjects involved. But as the issue brought into question iatrogenesis, the intention, the possibility and the success it refers to a peculiarity: about the little- spoken and almost-nothing-spoken. Still, the peculiarity of the little-spoken and of the almost-nothing-spoken was, perhaps, exactly because of that, potentialized in its analysis. That is, based in this theoretical framework, the idea was to break down and to give voice to the silencing regarding the issue of iatrogenesis.

The documentary sources and interviews with intensive care nurses, under the Foucauldian assumption, allowed the logic of normative system analysis applied to the nursing profession to be overcome. That is, we activated a reflection on the act of the nurse in a context permeated by the ever latent possibility of failure both in the procedure and in the conduct and, from that possibility, the nurse should meet their obligation to correct this failure, not so much or not only in knowledge, not so much or not only in law, but in practice itself.

\section{References}

1. Zoboli ELCP, Fortes PAC. Novas pontes para a bioética: do individual ao coletivo, da alta especialização à atenção básica. $O$ Mundo da Saúde. 2004 janeiro-março; 28(1):28-33.

2. Moreira RM, Padilha KG. Ocorrências iatrogênicas com pacientes submetidos à ventilação mecánica em unidade de terapia intensiva. Acta Paul Enferm. 2001 maio-agosto; 14(2):9-18.

3. Freitas GF, Oguisso T. Ocorrências éticas na enfermagem. Rev Bras Enferm. nov-dez 2003; 56(6):637-9.

4. Padilha KG. Iatrogenia em enfermagem na unidade de terapia intensiva: análise multidimensional do problema. Nota prévia. Rev Esc Enferm USP. abril 1988; 22(1):141-3.

5. Nascimento CCP, Toffoletto MC, Gonçalves LA, Freitas WG, Padilha KG. Indicadores de resultados da assistência: análise dos eventos adversos durante a internação hospitalar. Rev. Latino-Am. Enfermagem. [Internet]. ago 2008 [acesso 30 abr. 2010]; 16(4): 746-51. Disponível em: http:// www.scielo.br/scielo.php?script=sci_arttext\&pid $=$ S0104$11692008000400015 \&$ lng=pt. doi: 10.1590/S010411692008000400015.

6. Lima REF, Cassiani SHB. Interações medicamentosas potenciais em pacientes de unidade de terapia intensiva de um Hospital Universitário. Rev. Latino-Am. Enfermagem. [Internet]. abr 2009 [acesso 30 abr. 30]; 17(2):222-7. Disponível em: http://www.scielo.br/scielo.php?script=sci_ arttext\&pid=S0104-1692009000200013\&lng=pt. doi: $10.1590 /$ S0104-11692009000200013.
7. Silva SC, Padilha KG. Parada cardiorrespiratória na unidade de terapia intensiva: considerações teóricas sobre os fatores relacionados às ocorrências iatrogênicas. Rev Esc Enferm USP. 2001; 35(4):360-5.

8. Mendes HWB, Caldas AL Júnior. Infrações éticas envolvendo pessoal de enfermagem. Rev. Latino-Am. Enfermagem. dez 1999; 7(5):5-13.

9. Freitas GF, Oguisso T, Merighi MAB. Ocorrências éticas de enfermagem: cotidiano de enfermeiros gerentes e membros da comissão de ética de enfermagem. Rev. Latino-Am. Enfermagem. jul.-ago. 2006; 14(4):497-502.

10. Freitas GFF, Oguisso T, Merighi MAB. Motivações do agir de enfermeiros nas ocorrências éticas de enfermagem. Acta Paul Enferm. jan.-mar. 2006; 19(1):76-81.

11. Foucault M. A hermenêutica do sujeito. 2 ed. São Paulo: Martins Fontes; 2006.

12. Padilha KG, Kitahara PH, Gonçalves CCS, Sanches ALC. Ocorrências iatrogênicas com medicação em unidade de terapia intensiva: condutas adotadas e sentimentos expressos pelos enfermeiros. Rev Esc Enferm USP. 2002; 36(1):50-7.

13. Figueroa AA. Tecnología y bioética en enfermería: un desafío permanente. Texto Contexto Enferm. 2000; 9(1):9-24.

14. Camargo MNV, Padilha KG. Ocorrências iatrogênicas com medicação em unidades de terapia intensiva. Acta Paul Enferm. out.-dez. 2003; 16(4):69-76.

15. Maliandi R. Ética: dilemas y convergências: cuestiones éticas de la identidad, la globalización y la tecnología. Buenos Aires: Biblos-Universidad Nacional de Lanús; 2006.

Received: Dec. $4^{\text {th }} 2009$

Accepted: Jul. $15^{\text {th }} 2010$ 